\title{
Research on Evaluation Methods and Models of Teaching Ability of Aerobics Based on Multiple Intelligences Theory
}

\author{
Shuhe Shao \\ Department of Physical Education, Henan Institute of Science and Technology, \\ Xinxiang, 453003, China P.R \\ qianguoximi@163.com
}

\begin{abstract}
Teaching ability of aerobics is crucial to the development of aerobics athletes. It is also an effective way to evaluate the qualification of an aerobics coach. Aerobics teaching has many limitations. Current evaluation model of teaching ability of aerobics is far from complete. Thus, this paper proposes an optimized evaluation method and model of teaching ability of aerobics based on multiple intelligence theory. It constructs an evaluation index system of teaching ability of aerobics, taking into account aerobics teaching design, teaching implementation and teaching effective. Indicators are assigned weight. By analyzing the grey correlation degree between different indicators of teaching ability of aerobics and the optimal indicator, we can get the evaluation result for teaching ability of aerobics. An empirical study proves that the evaluation method has efficacy.
\end{abstract}

Keywords: multiple intelligence theory; aerobics; teaching ability; evaluation method and model; grey correlation analysis

\section{Introduction}

Aerobics teaching is crucial to produce excellent aerobics athletes [1-3]. However, as a newly developing subject, the evaluation system and method of teaching ability are far from mature. Though experts and scholars have studied it from different perspectives [4-7], there lacks a unified or standard index system and evaluation model of teaching ability of aerobics. What's more, current evaluations on teaching ability of aerobics have many limitations. For example: (1) the evaluation subjects are onefolded. The correlation and interaction between subjects are not clear. So teaching ability of aerobics cannot be measured in a scientific way; (2) the evaluation only focuses on one or several types of ability. So teaching ability of aerobics cannot be measured in a comprehensive way; (3) grade evaluation is always qualitative. And there are no quantitative models. So teaching ability of aerobics cannot be measured in a quantitative way. Thus, this paper proposes evaluation method and model of teaching ability of aerobics based on multiple intelligence theory [8-10]. It constructs an evaluation index system and an evaluation model according to grey correlation analysis ${ }^{[11-13]}$ to fulfill the purpose of evaluating teaching ability of aerobics.

\section{Evaluation Index System of Teaching Ability of Aerobics based on Multiple Intelligence Theory}

Multiple intelligence theory was first proposed by Howard Gardner, a developmental psychologist from Harvard Graduate School of Education. He holds that one's learning ability includes Verbal/Linguistic ability, Logical/Mathematical ability, Visual/Spatial 
ability, Bodily/Kinesthetic ability), Musical/Rhythmic ability, Inter-personal/Social ability, (Intra-personal/Introspective ability, Naturalist ability and so on. The evaluation of teaching ability of aerobics based on multiple intelligence theory can better reveal the relationship between teaching and learning, and thus measures the teaching ability of aerobics from multiple perspectives. This paper constructs the evaluation index system from teaching design ability, teaching implementation ability and teaching effectiveness.

\subsection{Evaluation Index System of Design Ability of Aerobics Teaching}

The design ability is used to measure preparations and basic qualities of teaching. Main components of the design ability are shown in Table 1.

Table 1. Evaluation Index System of Design Ability of Aerobics Teaching

\begin{tabular}{|c|c|}
\hline $\begin{array}{l}\text { Evaluation } \\
\text { system }\end{array}$ & Evaluation indicator \\
\hline \multirow{12}{*}{$\begin{array}{l}\text { Evaluation } \\
\text { index } \\
\text { system of } \\
\text { design } \\
\text { ability of } \\
\text { aerobics } \\
\text { teaching } \\
R^{1}\end{array}$} & Teaching-planning ability $r_{01}^{1}$ \\
\hline & $\begin{array}{l}\text { Advancement of teaching method } \\
r_{02}^{1}\end{array}$ \\
\hline & Familiarity with the textbook $r_{03}^{1}$ \\
\hline & $\begin{array}{l}\text { Abundance of teaching content } \\
r_{04}^{1}\end{array}$ \\
\hline & Completion of teaching tasks $r_{05}^{1}$ \\
\hline & Innovation of teaching style $r_{04}^{1}$ \\
\hline & Image processing ability $r_{07}^{1}$ \\
\hline & $\begin{array}{l}\text { Action choreographing capability } \\
r_{08}^{1}\end{array}$ \\
\hline & $\begin{array}{l}\text { Music choreographing capability } \\
r_{09}^{1}\end{array}$ \\
\hline & $\begin{array}{l}\text { Number of subjects on teaching } \\
\text { reform } r_{10}^{1}\end{array}$ \\
\hline & $\begin{array}{l}\text { Number of papers on teaching } \\
\text { reform } r_{11}^{1}\end{array}$ \\
\hline & $\begin{array}{l}\text { Number of subjects on scientific } \\
\text { research } r_{12}^{1}\end{array}$ \\
\hline
\end{tabular}

\subsection{Evaluation Index System of Implementation Ability of Aerobics Teaching}

The implementation ability is used to measure teaching content and implementation of teaching. Main components of the design ability are shown in Table 2. 


\section{Table 2. Evaluation Index System of Implementation Ability of Aerobics} Teaching

\begin{tabular}{l|l}
\hline $\begin{array}{l}\text { Evaluation } \\
\text { system }\end{array}$ & Evaluation indicator \\
\hline \multirow{4}{*}{$\begin{array}{l}\text { Evaluation } \\
\text { index system } \\
\text { of } \\
\text { implementation } \\
\text { ability of } \\
\text { aerobics } \\
\text { teaching } R^{2}\end{array}$} & Language application ability $r_{01}^{2}$ \\
\cline { 2 - 2 } & Professional knowledge $r_{02}^{2}$ \\
\cline { 2 - 2 } & Sense of direction $r_{03}^{2}$ \\
\cline { 2 - 2 } & Sense of music $r_{05}^{2}$ \\
\cline { 2 - 2 } & Teamwork $r_{06}^{2}$ \\
\cline { 2 - 2 } & Apnovation ability $r_{07}^{2}$ \\
\cline { 2 - 2 } & Knowledge integration ability $r_{09}^{2}$ \\
\cline { 2 - 2 } & Teaching management ability $r_{10}^{2}$ \\
\hline
\end{tabular}

\subsection{Evaluation Index System of Effectiveness of Aerobics Teaching}

The teaching effectiveness is used to measure the effectiveness of teaching. Main components of the design ability are shown in Table 3.

Table 3. Evaluation Index System of Effectiveness of Aerobics Teaching

\begin{tabular}{|c|c|}
\hline $\begin{array}{l}\text { Evaluation } \\
\text { system }\end{array}$ & Evaluation indicator \\
\hline \multirow{10}{*}{$\begin{array}{l}\text { Evaluation } \\
\text { index } \\
\text { system of } \\
\text { effectiveness } \\
\text { of aerobics } \\
\text { teaching } R^{3}\end{array}$} & Number of teaching awards $r_{01}^{3}$ \\
\hline & $\begin{array}{l}\text { Number of scientific research } \\
\text { awards } r_{02}^{3}\end{array}$ \\
\hline & Number of qualified students $r_{03}^{3}$ \\
\hline & Ratio of excellent students $r_{04}^{3}$ \\
\hline & $\begin{array}{l}\text { Number of race with student } \\
\text { participation } r_{05}^{3}\end{array}$ \\
\hline & $\begin{array}{l}\text { Number of awards obtained by } \\
\text { students } r_{06}^{3}\end{array}$ \\
\hline & $\begin{array}{l}\text { Social service ability of students } \\
r_{07}^{3}\end{array}$ \\
\hline & Innovation ability of students $r_{08}^{3}$ \\
\hline & Techniques of students $r_{09}^{3}$ \\
\hline & Social satisfaction on students $r_{10}^{3}$ \\
\hline
\end{tabular}




\section{Evaluation and Model of Teaching Ability of Aerobics}

\subsection{Weight of Indicators of Teaching Ability of Aerobics based on AHP}

To make the weight of indicators more objective, accurate and reasonable, AHP is introduced to assign the weight. Experts are invited to score on indicators. Here we can get the initial judgment matrix $\boldsymbol{T}$, namely,

$$
\boldsymbol{T}=\left[\begin{array}{ccccc}
t_{11} & \cdots & t_{1 i} & \cdots & t_{1 n} \\
\vdots & \cdots & \vdots & \cdots & \vdots \\
t_{i 1} & \cdots & t_{i i} & \cdots & t_{i n} \\
\vdots & \cdots & \vdots & \cdots & \vdots \\
t_{n 1} & \cdots & t_{n i} & \cdots & t_{n n}
\end{array}\right]
$$

Where $t_{i j}$ is the judgment value, $n$ is the number of indicators. There is $1 \leq i, j \leq n$.

Obtain the Maximum Eigenvalue $\max \left(\lambda_{t}(\boldsymbol{T})\right)$ of judgment $\boldsymbol{T}$, so the consistency indicator $R_{C I}$ is:

$$
R_{C I}=\left(\max \left(\lambda_{t}(\boldsymbol{T})\right)-n\right) /(n-1)
$$

The consistency ratio $R_{C R}$ is:

$R_{C R}=R_{C I} / R_{R I}$

If $R_{C I}$ and $R_{C R}$ can meet the threshold, the weight ${ }^{w_{i}}$ of indicator is:

$$
w_{i}=\sum_{j=1}^{n} p_{i j} / \sum_{i=1}^{n} \sum_{j=1}^{n} p_{i j}
$$

Thus, the weight sequence $\boldsymbol{W}$ of indicators of teaching ability of aerobics is:

$\boldsymbol{W}=\left[w_{1}, \cdots, w_{i}, \cdots, w_{n}\right]$

\subsection{Evaluation Model of Teaching Ability of Aerobics based on Grey Correlation Analysis}

Some indicators of teaching ability of aerobics are qualitative while others are quantitative. Thus, it is necessary to standardize them to apply grey correlation analysis. Qualitative indicators are shifted to quantitative description through fuzzy language, as is shown in Table 4.

Table 4. The Shift of Qualitative indicators

\begin{tabular}{c|c|c}
\hline \multirow{2}{*}{$\begin{array}{c}\text { Value } \\
\text { quantity }\end{array}$} & of & Definition \\
\cline { 3 - 3 } & $\begin{array}{c}\text { Positive } \\
\text { indicator }\end{array}$ & $\begin{array}{c}\text { Negative } \\
\text { indicator }\end{array}$ \\
\hline 1.0 & Excellent & Unbearable \\
\hline 0.8 & Good & Undesirable \\
\hline
\end{tabular}




\begin{tabular}{l|l|l}
\hline 0.6 & Mediocre & Poor \\
\hline 0.4 & Poor & Mediocre \\
\hline 0.2 & $\mathrm{e}^{\text {Undesirabl }}$ & Good \\
\hline 0 & $\mathrm{e}^{\text {Unbearabl }}$ & Excellent \\
\hline $\begin{array}{l}0.1,0.3,0.5 .0 .7, \\
0.9\end{array}$ & $\begin{array}{c}\text { Between two values of } \\
\text { quantity }\end{array}$ \\
\hline
\end{tabular}

If a quantitative indicator $j$ is a positive indicator and its initial value of quantity is $r_{i j}$, so the value of quantity after standardization is $v_{i j}$ :

$v_{i j}=\left(r_{i j}-\min _{1 \leq i \leq m} r_{i j}\right) /\left(\max _{1 \leq i \leq m} r_{i j}-\min _{1 \leq i \leq m} r_{i j}\right)$

Where $m$ is the number of evaluation subject.

If a quantitative indicator $j$ is a negative indicator, expression (6) becomes:

$v_{i j}=\left(\max _{1 \leq i \leq m} r_{i j}-r_{i j}\right) /\left(\max _{1 \leq i \leq m} r_{i j}-\min _{1 \leq i \leq m} r_{i j}\right)$

Thus, we can get the standard series $\boldsymbol{v}_{o}$ for grey correlation analysis, namely,

$$
\begin{aligned}
\boldsymbol{v}_{o} & =\left[v_{o 1}, \cdots, v_{o j}, \cdots, v_{o n}\right] \\
& =\left[\max _{1 \leq i \leq m} v_{i 1}, \cdots, \max _{1 \leq i \leq m} v_{i j}, \cdots, \max _{1 \leq i \leq m} v_{o n}\right]
\end{aligned}
$$

The grey correlation coefficient $\eta_{i j}$ between indicator $j$ about subject $i$ and the standard series $\boldsymbol{v}_{o}$ is:

So the grey correlation matrix $\boldsymbol{\eta}$ is:

\subsection{The Realization of Evaluation Model of Teaching Ability of Aerobic}

Based on weight sequence $\boldsymbol{W}$, the grey correlation degree $\delta$ between the subject and the standard series $\boldsymbol{v}_{o}$ is:

Suppose the grey correlation degree of the index system $R^{k}$ about subject $i$ is $\delta_{i}^{R^{k}}$, the grey correlation matrix $\boldsymbol{\delta}^{R}$ is:

If the weight of the index system is $w_{R^{k}}$, the comprehensive weighed grey correlation degree about the subject $i$ is $\kappa_{i}$ :

According to $\kappa_{i}$, we can find out the optimal subject of teaching ability of aerobics, following the principle expressed as (14):

$$
\kappa_{o}^{\square}=\max \left[\kappa_{1}^{\square}, \cdots, \kappa_{i}^{\square}, \cdots, \kappa_{m}^{\square}\right]=\kappa_{p}^{\square}
$$

Subject $p$ has the best teaching ability of aerobics. 


\section{Empirical Study}

Institute of Physical Education implemented talent projects and produced many excellent players. This plays an active role in promoting the development of the institution. So, it is significant to evaluate the performance of students in the talent projects. This paper takes students in the talent projects as the subjects in order to test the model. Tables 5, 6 and 7 show evaluation data of three talents.

\section{Table 5. Evaluation Data of Three Subjects for Design Ability of Aerobics} Teaching

\begin{tabular}{|c|c|c|c|c|}
\hline \multirow{2}{*}{$\begin{array}{l}\text { Evaluation } \\
\text { system }\end{array}$} & \multirow{2}{*}{ Evaluation indicator } & \multicolumn{3}{|c|}{ Evaluation data } \\
\hline & & A & $\mathrm{B}$ & $\mathrm{C}$ \\
\hline \multirow{12}{*}{$\begin{array}{l}\text { Evaluation } \\
\text { index } \\
\text { system of } \\
\text { design } \\
\text { ability of } \\
\text { aerobics } \\
\text { teaching } R^{1}\end{array}$} & $\begin{array}{l}\text { Teaching-planning } \\
\text { ability } r_{01}^{1}\end{array}$ & 0.90 & 0.90 & 1.00 \\
\hline & $\begin{array}{l}\text { Advancement of } \\
\text { teaching method } r_{02}^{1}\end{array}$ & 1.00 & 0.90 & 0.80 \\
\hline & $\begin{array}{l}\text { Familiarity with the } \\
\text { textbook } r_{03}^{1}\end{array}$ & 0.90 & 1.00 & 0.90 \\
\hline & $\begin{array}{l}\text { Abundance of teaching } \\
\text { content } r_{04}^{1}\end{array}$ & 1.00 & 0.85 & 0.90 \\
\hline & $\begin{array}{l}\text { Completion of teaching } \\
\text { tasks } r_{05}^{1}\end{array}$ & 1.00 & 1.00 & 0.90 \\
\hline & $\begin{array}{l}\text { Innovation of teaching } \\
\text { style } r_{04}^{1}\end{array}$ & 1.00 & 1.00 & 0.85 \\
\hline & $\begin{array}{l}\text { Image processing ability } \\
r_{07}^{1}\end{array}$ & 0.90 & 0.85 & 1.00 \\
\hline & $\begin{array}{l}\text { Action choreographing } \\
\text { capability } r_{08}^{1}\end{array}$ & 1.00 & 0.90 & 0.90 \\
\hline & $\begin{array}{l}\text { Music choreographing } \\
\text { capability } r_{09}^{1}\end{array}$ & 1.00 & 0.90 & 0.90 \\
\hline & $\begin{array}{l}\text { Number of subjects on } \\
\text { teaching reform } r_{10}^{1}\end{array}$ & 3 & 2 & 2 \\
\hline & $\begin{array}{l}\text { Number of papers on } \\
\text { teaching reform } r_{11}^{1}\end{array}$ & 6 & 7 & 8 \\
\hline & $\begin{array}{l}\text { Number of subjects on } \\
\text { scientific research } r_{12}^{1}\end{array}$ & 4 & 2 & 3 \\
\hline
\end{tabular}




\section{Table 6. Evaluation Data of Three Subjects for Implementation Ability of Aerobics Teaching}

\begin{tabular}{|c|c|c|c|c|}
\hline \multirow{2}{*}{$\begin{array}{l}\text { Evaluation } \\
\text { system }\end{array}$} & \multirow{2}{*}{ Evaluation indicator } & \multicolumn{3}{|c|}{ Evaluation data } \\
\hline & & A & $\mathrm{B}$ & $\mathrm{C}$ \\
\hline \multirow{10}{*}{$\begin{array}{l}\text { Evaluation } \\
\text { index system } \\
\text { of } \\
\text { implementation } \\
\text { ability of } \\
\text { aerobics } \\
\text { teaching } R^{2}\end{array}$} & $\begin{array}{l}\text { Language application } \\
\text { ability } r_{01}^{2}\end{array}$ & 0.85 & 1.00 & 0.90 \\
\hline & Professional knowledge $r_{02}^{2}$ & 1.00 & 0.90 & 0.85 \\
\hline & Sense of direction $r_{03}^{2}$ & 0.90 & 1.00 & 0.80 \\
\hline & Action teaching ability $r_{04}^{2}$ & 0.95 & 0.90 & 1.00 \\
\hline & Sense of music $r_{05}^{2}$ & 0.85 & 1.00 & 0.90 \\
\hline & Teamwork $r_{06}^{2}$ & 0.80 & 1.00 & 0.90 \\
\hline & Innovation ability $r_{07}^{2}$ & 1.00 & 0.90 & 1.00 \\
\hline & Appreciation ability $r_{08}^{2}$ & 1.00 & 0.90 & 0.85 \\
\hline & $\begin{array}{l}\text { Knowledge integration } \\
\text { ability } r_{09}^{2}\end{array}$ & 1.00 & 0.85 & 0.80 \\
\hline & $\begin{array}{l}\text { Teaching management } \\
\text { ability } r_{10}^{2}\end{array}$ & 0.90 & 1.00 & 1.00 \\
\hline
\end{tabular}

Table 7. Evaluation Data of Three Subjects for Effectiveness of Aerobics Teaching

\begin{tabular}{|c|c|c|c|c|}
\hline \multirow{2}{*}{$\begin{array}{l}\text { Evaluation } \\
\text { system }\end{array}$} & \multirow{2}{*}{ Evaluation indicator } & \multicolumn{3}{|c|}{ Evaluation data } \\
\hline & & A & $\mathrm{B}$ & $\mathrm{C}$ \\
\hline \multirow{8}{*}{$\begin{array}{l}\text { Evaluation } \\
\text { index } \\
\text { system of } \\
\text { effectiveness } \\
\text { of aerobics } \\
\text { teaching } R^{3}\end{array}$} & $\begin{array}{l}\text { Number of teaching } \\
\text { awards } r_{01}^{3}\end{array}$ & 1 & 1 & 1 \\
\hline & $\begin{array}{l}\text { Number of scientific } \\
\text { research awards } r_{02}^{3}\end{array}$ & 1 & 0 & 1 \\
\hline & $\begin{array}{l}\text { Number of qualified } \\
\text { students } r_{03}^{3}\end{array}$ & 3 & 4 & 4 \\
\hline & $\begin{array}{l}\text { Ratio of excellent } \\
\text { students } r_{04}^{3}\end{array}$ & 0.33 & 0.25 & 0 \\
\hline & $\begin{array}{l}\text { Number of race with } \\
\text { student participation } \\
r_{05}^{3}\end{array}$ & 12 & 16 & 16 \\
\hline & $\begin{array}{l}\text { Number of awards } \\
\text { obtained by students } \\
r_{06}^{3}\end{array}$ & 4 & 5 & 5 \\
\hline & $\begin{array}{l}\text { Social service ability } \\
\text { of students } r_{07}^{3}\end{array}$ & 1.00 & 0.85 & 0.95 \\
\hline & Innovation ability of & 0.85 & 1.00 & 0.85 \\
\hline
\end{tabular}




\begin{tabular}{l|l|l|l|l}
\hline & students $r_{08}^{3}$ & & & \\
\cline { 2 - 5 } & $\begin{array}{l}\text { Techniques of } \\
\text { students } r_{09}^{3}\end{array}$ & 1.00 & 0.85 & 1.00 \\
\cline { 2 - 5 } & $\begin{array}{l}\text { Social satisfaction on } \\
\text { students } r_{10}^{3}\end{array}$ & 1.00 & 0.80 & 0.85 \\
\hline & $\begin{array}{l}\text { Social satisfaction on } \\
\text { students } r_{10}^{3}\end{array}$ & 1.00 & 0.80 & 0.85 \\
\hline
\end{tabular}

According to the evaluation model of teaching ability of aerobics proposed in this paper based on grey correlation analysis, we can get the grey correlation coefficient for each evaluation subject, as is shown in Table 8, 9 and 10.

Table 8. Gray Correlation Coefficient of Design Ability of Aerobics Teaching for Three Subjects

\begin{tabular}{|c|c|c|c|c|}
\hline \multirow{2}{*}{$\begin{array}{l}\text { Evaluation } \\
\text { system }\end{array}$} & \multirow{2}{*}{ Evaluation indicator } & \multicolumn{3}{|c|}{ Evaluation data } \\
\hline & & $\mathrm{A}$ & $\mathrm{B}$ & $\mathrm{C}$ \\
\hline \multirow{12}{*}{$\begin{array}{l}\text { Evaluation } \\
\text { index } \\
\text { system of } \\
\text { design } \\
\text { ability of } \\
\text { aerobics } \\
\text { teaching } R^{1}\end{array}$} & $\begin{array}{l}\text { Teaching-planning } \\
\text { ability } r_{01}^{1}\end{array}$ & 0.714 & 0.714 & 1.000 \\
\hline & $\begin{array}{l}\text { Advancement of } \\
\text { teaching method } r_{02}^{1}\end{array}$ & 1.000 & 0.714 & 0.556 \\
\hline & $\begin{array}{l}\text { Familiarity with the } \\
\text { textbook } r_{03}^{1}\end{array}$ & 0.714 & 1.000 & 0.714 \\
\hline & $\begin{array}{l}\text { Abundance of teaching } \\
\text { content } r_{04}^{1}\end{array}$ & 1.000 & 0.625 & 0.714 \\
\hline & $\begin{array}{l}\text { Completion of teaching } \\
\text { tasks } r_{05}^{1}\end{array}$ & 1.000 & 1.000 & 0.714 \\
\hline & $\begin{array}{l}\text { Innovation of teaching } \\
\text { style } r_{04}^{1}\end{array}$ & 1.000 & 1.000 & 0.625 \\
\hline & $\begin{array}{l}\text { Image processing ability } \\
r_{07}^{1}\end{array}$ & 0.714 & 0.625 & 1.000 \\
\hline & $\begin{array}{l}\text { Action choreographing } \\
\text { capability } r_{08}^{1}\end{array}$ & 1.000 & 0.714 & 0.714 \\
\hline & $\begin{array}{l}\text { Music choreographing } \\
\text { capability } r_{09}^{1}\end{array}$ & 1.000 & 0.714 & 0.714 \\
\hline & $\begin{array}{l}\text { Number of subjects on } \\
\text { teaching reform } r_{10}^{1}\end{array}$ & 1.000 & 0.667 & 0.667 \\
\hline & $\begin{array}{l}\text { Number of papers on } \\
\text { teaching reform } r_{11}^{1}\end{array}$ & 0.500 & 0.875 & 1.000 \\
\hline & $\begin{array}{l}\text { Number of subjects on } \\
\text { scientific research } r_{12}^{1}\end{array}$ & 1.000 & 0.333 & 0.500 \\
\hline
\end{tabular}


Table 9. Gray Correlation Coefficient of Implementation Ability of Aerobics teaching for Three Subjects

\begin{tabular}{|c|c|c|c|c|}
\hline \multirow{2}{*}{$\begin{array}{l}\text { Evaluation } \\
\text { system }\end{array}$} & \multirow{2}{*}{ Evaluation indicator } & \multicolumn{3}{|c|}{ Evaluation data } \\
\hline & & A & $\mathrm{B}$ & $\mathrm{C}$ \\
\hline \multirow{10}{*}{$\begin{array}{l}\text { Evaluation } \\
\text { index system } \\
\text { of } \\
\text { implementation } \\
\text { ability of } \\
\text { aerobics } \\
\text { teaching } R^{2}\end{array}$} & $\begin{array}{l}\text { Language application } \\
\text { ability } r_{01}^{2}\end{array}$ & 0.400 & 1.000 & 0.500 \\
\hline & Professional knowledge $r_{02}^{2}$ & 1.000 & 0.500 & 0.400 \\
\hline & Sense of direction $r_{03}^{2}$ & 0.500 & 1.000 & 0.333 \\
\hline & Action teaching ability $r_{04}^{2}$ & 0.667 & 0.500 & 1.000 \\
\hline & Sense of music $r_{05}^{2}$ & 0.400 & 1.000 & 0.500 \\
\hline & Teamwork $r_{06}^{2}$ & 0.333 & 1.000 & 0.500 \\
\hline & Innovation ability $r_{07}^{2}$ & 1.000 & 0.500 & 1.000 \\
\hline & Appreciation ability $r_{08}^{2}$ & 1.000 & 0.500 & 0.400 \\
\hline & $\begin{array}{l}\text { Knowledge integration } \\
\text { ability } r_{09}^{2}\end{array}$ & 1.000 & 0.400 & 0.333 \\
\hline & $\begin{array}{l}\text { Teaching management } \\
\text { ability } r_{10}^{2}\end{array}$ & 0.500 & 1.000 & 1.000 \\
\hline
\end{tabular}

Table 10. Gray Correlation Coefficient of Effectiveness of Aerobics Teaching for Three Subjects

\begin{tabular}{|c|c|c|c|c|}
\hline \multirow{2}{*}{$\begin{array}{l}\text { Evaluation } \\
\text { system }\end{array}$} & \multirow{2}{*}{ Evaluation indicator } & \multicolumn{3}{|c|}{ Evaluation data } \\
\hline & & $\mathrm{A}$ & $\mathrm{B}$ & $\mathrm{C}$ \\
\hline \multirow{8}{*}{$\begin{array}{l}\text { Evaluation } \\
\text { index } \\
\text { system of } \\
\text { effectiveness } \\
\text { of aerobics } \\
\text { teaching } R^{3}\end{array}$} & $\begin{array}{l}\text { Number of teaching } \\
\text { awards } r_{01}^{3}\end{array}$ & 1.000 & 1.000 & 1.000 \\
\hline & $\begin{array}{l}\text { Number of scientific } \\
\text { research awards } r_{02}^{3}\end{array}$ & 1.000 & 0.111 & 1.000 \\
\hline & $\begin{array}{l}\text { Number of qualified } \\
\text { students } r_{03}^{3}\end{array}$ & 0.333 & 1.000 & 1.000 \\
\hline & $\begin{array}{l}\text { Ratio of excellent } \\
\text { students } r_{04}^{3}\end{array}$ & 1.000 & 0.340 & 0.111 \\
\hline & $\begin{array}{l}\text { Number of race with } \\
\text { student participation } \\
r_{05}^{3}\end{array}$ & 0.333 & 1.000 & 1.000 \\
\hline & $\begin{array}{l}\text { Number of awards } \\
\text { obtained by students } \\
r_{06}^{3}\end{array}$ & 0.385 & 1.000 & 1.000 \\
\hline & $\begin{array}{l}\text { Social service ability } \\
\text { of students } r_{07}^{3}\end{array}$ & 1.000 & 0.455 & 0.714 \\
\hline & Innovation ability of & 0.455 & 1.00 & 0.455 \\
\hline
\end{tabular}




\begin{tabular}{l|l|l|l|l}
\hline & students $r_{08}^{3}$ & & & \\
\cline { 2 - 5 } & $\begin{array}{l}\text { Techniques of } \\
\text { students } r_{09}^{3}\end{array}$ & 1.000 & 0.455 & 1.00 \\
\cline { 2 - 5 } & $\begin{array}{l}\text { Social satisfaction on } \\
\text { students } r_{10}^{3}\end{array}$ & 1.000 & 0.385 & 0.455 \\
\hline
\end{tabular}

Thus, we can get the grey correlation matrix of index system for each subject, namely,

According to weight assignment in AHP, the weigh for each index system is 0.186 , 0.356 and 0.458 . So the comprehensive weighed grey correlation sequence is:

From the sequence, we can see subject $\mathrm{A}$ is the best among three subjects from the Institute of Physical Education.

\section{Conclusions}

Targeting at limitations of the analysis of teaching ability of aerobics, this paper proposes an evaluation method and model of teaching ability of aerobic based on multiple intelligence theory. Its contributions lies in: (1) it first constructs the evaluation index system of teaching ability of aerobics based on multiple intelligence theory while taking into account design, implementation and effectiveness of aerobics teaching, making the evaluation more reasonable and scientific; (2) it constructs the grey correlation analysis model in which quantitative and qualitative evaluation are combined, making the evaluation easier to operate; (3) the index system of teaching ability of aerobics is quite clear with definite physical definitions, and easy to achieve on the computer. It provides support for the intelligent analysis of teaching ability of aerobics; (4) the empirical study proves that the model can serve the research purpose well.

\section{References}

[1] L. Zhang, "Research and practice of the diversified evaluation mode for aerobics course teaching at colleges and universities: Taking Fuzhou University as a case", Journal of Fujian Agriculture and Forestry University (Philosophy and Social Sciences), vol. 15, no. 5, (2012), pp. 100-103.

[2] X. Chen, "Influence factors of aerobics teaching performance-Case study of colleges in Xinxiang area", Wuzhou University Journal, vol. 3, (2010), pp. 81-85

[3] M. Zhang, "Reforming experiment of evaluating method of aerobics course in physical education of normal colleges", Journal Of Chengdu Sport University, vol. 32, no. 6, (2006), pp. 104-106.

[4] Z. Jin, "Constructing evaluation model for teaching ability of aerobics teachers in colleges", Journal of Chifeng University, vol. 30, no. 8, (2014), pp. 125-128.

[5] H. Du, 'Evaluation of aerobics teaching from the perspectives of multiple intelligence revisited [J]", School Physical Education, vol. 4, no. 26, (2014), pp.102-104.

[6] X. Chen, "Optimized evaluation standard and approach of aerobics teaching", sports world, vol. 9, (2008), pp. 23-25.

[7] D. Zhang, 'Empirical study of the application of multiple intelligence theory in aerobics as an optional course", Journal of jilin normal university (natural science edition), vol. 2, (2011), pp. 128130.

[8] N. Weilin, "Establishing the system of the pe and health course evaluation using multi-intelligent theory', Journal of Xi'an University of Physical Education, vol. 4, (2006), pp. 110-112. 


\section{Author}

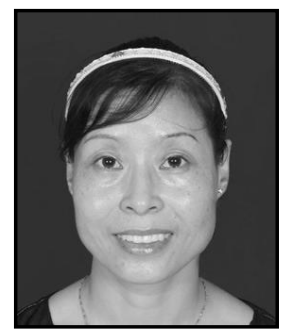

Shuhe Shao, she received her M.D. in sports science (2005) from University. Now she is a lecturer of sports science at Department of Physical Education, University. Her current research interests include different aspects of the application of computer model in the sports. 
International Journal of Hybrid Information Technology Vol.8, No.2 (2015) 